\title{
Geographic information Systems enforced to Occupational Health and Safety Practices: A short literature review
}

\author{
Carolina Garreto ${ }^{1}$, J. Duarte ${ }^{2}$, Jacqueline Castelo Branco 3 , J. C. Guedes ${ }^{4}$
}

${ }^{1}$ Faculty of Engineering, University of Porto, PT (carolgarreto@gmail.com) ORCID 0000-0001-7138-7714, ${ }^{2}$ Associated Laboratory for Energy, Transports, and Aeronautics (PROA/LAETA), Faculty of Engineering, University of Porto, PT (jasduarte@fe.up.pt) ORCID 0000-0002-5856-5317, ${ }^{3}$ Associated Laboratory for Energy, Transports, and Aeronautics (PROA/LAETA), Faculty of Engineering, University of Porto, PT (jcb@fe.up.pt) ORCID 0000-00029254-4384, ${ }^{4}$ Associated Laboratory for Energy, Transports, and Aeronautics (PROA/LAETA), Faculty of Engineering, University of Porto, PT (jccg@fe.up.pt) ORCID 0000-0003-2367-2187

https://doi.org/10.24840/978-972-752-260-6_0115-0118

\begin{abstract}
Introduction: Risk assessment methods are commonly used in health and safety and require rapid response tools that allow an analysis of multiple scenarios in order to reduce the loss of life, environmental and materials damages. This work is a systematic review of the available literature of Geographic Information Systems (GIS), addressing issues related to the occupational sciences of Health and Safety and/or Emergency. Methodology: The method used for the review was based on the PRISMA-Statement. It was developed through 4 databases (Web of Science, Scopus, Springer Link, and Science Direct). The keywords used followed the logic (Occupational OR work) AND (hygiene OR health OR safety) AND (GIS). The applied databases filters were: document type limited to Article (research) and Article in the press, Journals source, and English and Portuguese languages. Results: It was identified a total of 667 items, 21 of which were selected for full-text reading. As a result, five articles were selected, and the other two were identified through their reference screening. The articles comprise the years 2009 to 2017, with authors of 9 nationalities and the use of monitoring being the most present method. ArcGIS (ESRI) software was the most frequently used. Information on the risk management methods, and the GIS as a platform, were obtained in mining, construction, industry, mainly, and addressed security issues (one article), emergency (two articles) and occupational hygiene (four articles).

Discussion: The results of the identified articles helped on issues such as decision making, escape routes, gas concentration information records, dust and fumes, temperature monitoring, humidity, identifying areas with exposure to ionizing radiation, noise, spots identification diseases and visualization of medical complaints conditions for the workplace. It also identified the evolution of the use of GIS information platform with other technologies allowing expansion of new types of evaluation. Conclusions: The developed search identified addressing issues in the areas of analysis and management of risks and emergencies, even those that are not exactly worked in safety and occupational hygiene, although it can be seen that the use of the experience is feasible, information and existing approaches to develop the concept of an integrated risk analysis and dynamics within the GIS.
\end{abstract}

Keywords: Geographic information system, Occupational hazards, Risk management, Emergencies.

\section{INTRODUCTION}

Risk assessment methods are commonly used in occupational health and safety to reduce accidents, risk mitigation, and prevention of diseases. The use of tools with faster and more functional responses may be essential to prevent accidents and reduce occupational diseases, so the usage of this technology in favor of this proposal can reduce costs and save lives (Delaunay et al., 2015). "A geographic information system (GIS) is a framework for gathering, managing, and analyzing data. It analyzes the spatial location and organizes layers of information into visualizations. GIS reveals deeper insights into data, such as patterns, relationships, and situations-helping users make smarter decisions." (ESRI, 2019). Thus, the GIS showed the use of characteristics relevant to what is sought by integrating data, overlay information and view responses in different contexts. It was used the safety classification for articles dealing with accidents and hygiene for those who talk about the exposure to environmental risks and health. The objective was to find evidence about the possible advantages of GIS-based techniques to support occupational safety and health (OSH) practices and support future work. 


\section{METHODOLOGY}

The description of this systematic review was made based on the guideline Preferred Reporting Items for Systematic Reviews and Meta-Analyzes (PRISMA Statement) (Moher et al., 2009). It began with the definition of the relevant keywords, used following the logic: (occupational OR work) AND (hygiene OR health OR safety) AND (GIS). The review was conducted mainly in four databases: Scopus, Web of Science, Springer link and Science Direct. The first research step was carried out in order to find more keywords and to recognize the scale of the issue. Screening procedures were based on selecting the titles dealing with the occupational context (e.g. industrial application, involving employees or bring the relationship to work). Moreover, as exclusion criteria were used: type of document (Article - research and Article in press), type of source (only Journals) and English and Portuguese languages. After the first selection and reading of articles, their references were reviewed to find the same context articles.

\section{RESULTS}

Searches resulted in 667 articles identified through databases. After selecting the relevant articles with the use of filters, 21 studies remain, fulfilling the criteria "On Topic". When performing screening, remained five articles developing topics related to occupational health and safety, and emergency context. After this selection, articles were separated according to the OSH goal areas (hygiene, safety, and emergency). The references of the included articles were analyzed and were added to this study two more articles that fulfill the criteria. The summary of the selected studies is in Table 1. These articles cover the period from 2009 to 2017, show authors and their research in nine nationalities, especially China with two items, and monitoring as the most frequent method. All items use GIS in combination with a range of different software, including several programming languages, Office software, databases and GIS complementary packages. Occupational activities that enable user interaction make use of Web GIS interface. Most of them use the ArcGIS (ESRI) software. As for the development area related to OHS, four can be classified into occupational hygiene, two in the emergency part and one in the safety area. Four articles were developed in the mining area, but despite the quantitative relevance it was found research has been found in other types of significant industries.

\section{DISCUSSION}

With the collection of information on the use of risk management methods together with georeferencing platform (GIS) in several areas (mining, construction, industry) and the approach to various types of risks (physical, chemical, biological, accidents), It is possible to verify the real possibility of using the platform in occupational safety and emergency. Also, occupational hygiene area is covered with the methods of monitoring the conditions and monitoring of healthcare data (such as monitoring the evolution of the contamination, disease statistics, or similar). In the safety area, Manase et al. (2011) describe the points for GIS approach OSH in the context of construction in its various phases of work. The authors use ArcGIS together with Excel and Access, developing an information system that captures, analyzes and presents information to assist decision making in the context of accidents or diseases trend and financial information. In the emergency area, two articles studies work the issue with the implementation of monitoring systems. Salap (2009) considers GIS applied to safety in underground mining, to 
perform the dust concentration monitoring and ventilation requirements throughout a model developed in GIS with a web interface.

Table 1. Articles with SSHO topics

\begin{tabular}{|c|c|c|c|c|c|}
\hline Author, year & Countries & Research area & $\begin{array}{l}\text { Occupational } \\
\text { sector }\end{array}$ & Analysis method & $\begin{array}{l}\text { Program / } \\
\text { Version }\end{array}$ \\
\hline $\begin{array}{l}\text { (Salap, } \\
\text { Karslioğlu, \& } \\
\text { Demirel, 2009) }\end{array}$ & $\mathrm{TR}$ & Emergency & Mining & Monitoring air velocity & $\begin{array}{l}\text { Not } \\
\text { reported }\end{array}$ \\
\hline $\begin{array}{l}\text { (El-Harbawi et } \\
\text { al., 2010) }\end{array}$ & MW & $\begin{array}{l}\text { Chemicals - flammable } \\
\text { (emergency) / toxic }\end{array}$ & $\begin{array}{l}\text { Chemical and } \\
\text { petroleum }\end{array}$ & $\begin{array}{l}\text { Simulation of various } \\
\text { mathematical models for } \\
\text { different types of risk }\end{array}$ & ArcGIS \\
\hline $\begin{array}{l}\text { (Huang, Zhu, \& } \\
\text { Lu, 2010) }\end{array}$ & $\mathrm{CN}$ & Emergency & Mining & $\begin{array}{l}\text { Monitoring gases }\left(\mathrm{CH}_{4},\right. \\
\left.\mathrm{CO}_{2}\right) \text { and conditions of } \\
\text { ventilator equipment }\end{array}$ & WebGIS \\
\hline $\begin{array}{l}\text { (Manase et al., } \\
\text { 2011) }\end{array}$ & UK & Accidents prevention & Construction & $\begin{array}{l}\text { Process analysis and } \\
\text { collected data on the } \\
\text { occurrence of accidents }\end{array}$ & $\begin{array}{l}\text { ArcView } \\
\text { GIS } 3.3\end{array}$ \\
\hline $\begin{array}{l}\text { (Moridi et al., } \\
\text { 2015) }\end{array}$ & $A U, J P$ & $\begin{array}{l}\text { Temperature, humidity, and } \\
\text { concentration of gases }\end{array}$ & Mining & $\begin{array}{l}\text { Monitoring temperature, } \\
\text { humidity, and gases }\end{array}$ & $\begin{array}{l}\text { ArcGIS (not } \\
\text { reported } \\
\text { version) }\end{array}$ \\
\hline $\begin{array}{l}\text { (Delaunay et } \\
\text { al., 2015) }\end{array}$ & $\begin{array}{l}F R, Z A, \\
B E, U K\end{array}$ & $\begin{array}{l}\text { Ergonomic risks, lonizing } \\
\text { Radiation, Noise; } \\
\text { Electromagnetic Fields of } \\
\text { danger }\end{array}$ & Microelectronics & $\begin{array}{l}\text { Analysis of } \\
\text { samples/measurements }\end{array}$ & $\begin{array}{l}\text { ArcGIS (not } \\
\text { reported } \\
\text { version) }\end{array}$ \\
\hline $\begin{array}{l}\text { (Kouame, Jiang } \\
\text { Feng, \& Zhu, } \\
\text { 2017) }\end{array}$ & $\mathrm{CN}$ & Biohazards & $\begin{array}{l}\text { Mining } \\
\text { (Artisanal) }\end{array}$ & Monitoring real-time & $\begin{array}{l}\text { Not } \\
\text { reported }\end{array}$ \\
\hline
\end{tabular}

The database integrated WebGIS also supports, in case of an accident, the real-time decision on escape routes. This interface was chosen because it allows users to monitor and control critical data anytime from anywhere. Huang, Zhu, \& Lu (2010) present the design and implementation of ZigBee technology-based system and Web GIS underground mining location. The system is intended to assist the rescue of victims at work in the event of disaster or accident through records of users in the network monitoring. Regarding the issues of chemical, physical, biological, ergonomic and accident, they were found four articles that work these risks were found. El-Harbawi et al. (2010) developed the "simulation of chemical industrial accident - SCIA" software, GIS in conjunction with Visual Basic language, modeling the accidental release of flammable and toxic chemicals. These templates can be used to check the risks of radiation, pressure and toxic dispersion different scenarios. Moridi et al. (2015) address the sensing, capture, processing and sending information through Zigbee with GIS in mining areas. The information measured by sensors is collected by Zigbee wireless through us and sent to the GIS. It generates a risk management system in real time, sending alarm messages and warning to those involved in the activity. Delaunay et al. (2015) map the risks in an industrial plant showing the causative agents. It addresses the importance of GIS use for mapping of risks within the aluminum industry. Integrated maps obtained information from risk agents with information layers of the type of agent, amount of people, cases of disease/injury, allowing an integrated view of these factors. Kouame et al. (2017) use medical data in combination with GIS to reduce the risk of proliferation of epidemics and infectious diseases, identifying outbreaks of disease in people who work in mining, as well as control and reduce disaster mines during the operation. In general, the works that deal with real-time monitoring are more applicable in identifying conditions that exceed exposure limits and emergency management. In conjunction with the 
Web interface is shown to be efficient for decision making and verification of the conditions for all levels of management. Additionally, the introduction of new technologies aggregated to the GIS, such as the structure assembled with Zigbee, makes it possible to broaden the research field for new types of assessment.

\section{CONCLUSIONS}

The search gave seven articles, including five in the search data and two based on the review of its references. Countries with more researchers within the collected articles are China and the United Kingdom, and the identified research areas include occupational safety and hygiene and emergency issues. Most studies used the ArcGIS program, but without identifying its version. The absence of this information makes it difficult to replicate the performed work (original version and updated version of the program) to check if there have been significant improvements in responses after the software update. The review presents relevant studies developed in GIS, and with application in the analysis area, and risk management and emergencies, even if they were not specifically addressed by the occupational safety and hygiene field. The applications found in GIS were only applied in industries, which invested values in the prevention of accidents and injuries are reduced when related to the occurrence of accidents on an industrial scale (Albert \& Hallowell, 2013). Finally, it can be verified that the concept of an integrated and dynamic risk analysis using GIS is feasible, since there is already experience in the application of the platform within the theme, and the knowledge acquired in other areas can be used as well as the existing approaches to support the development of new techniques.

\section{References}

Albert, A., \& Hallowell, M. R. (2013). Safety risk management for electrical transmission and distribution line construction. Safety Science, 51(1), 118-126. https://doi.org/10.1016/j.ssci.2012.06.011

Delaunay, M., van der Westhuizen, H., Godard, V., Agius, R., Le Barbier, M., Godderis, L., \& Bonneterre, V. (2015). Use of GIS in visualization of work-related health problems. Occupational Medicine, 65(8), 682-692. https://doi.org/10.1093/occmed/kqv152

El-Harbawi, M., Mustapha, S., Choong, T. S. Y., Rashid, Z. A., Rashid, S. A., \& Sherif, A. A. (2010). SCIA: GIS-based software for assessing the impacts from chemical industrial accidents. Practice Periodical of Hazardous, Toxic, and Radioactive Waste Management, 14(2), 104-114. https://doi.org/10.1061/(ASCE)1090-025X(2010)14:2(104)

ESRI. (2019). What is GIS? Retrieved April 12, 2019, from https://www.esri.com/en-us/what-is-gis/overview

Huang, X., Zhu, W., \& Lu, D. (2010). Underground miners localization system based on ZigBee and WebGIS. 2010 18th International Conference on Geoinformatics, Geoinformatics 2010, 1-5. https://doi.org/10.1109/GEOINFORMATICS.2010.5567542

Kouame, K. J. A., Jiang, F., Feng, Y., \& Zhu, S. (2017). The Strengthening of Geological Infrastructure, Research and Data Acquisition - Using Gis in Ivory Coast Gold Mines. MATEC Web of Conferences, 95, 18001. https://doi.org/10.1051/matecconf/20179518001

Manase, D., Heesom, D., Oloke, D., Proverbs, D., Young, C., \& Luckhurst, D. (2011). A gis analytical approach for exploiting construction health and safety information. Electronic Journal of Information Technology in Construction, 16, 335-356. Retrieved from https://www.scopus.com/inward/record.uri?eid=2-s2.079954487340\&partnerlD=40\&md5=7194db4d8cbbf3f19a60b02043356ac2

Moher, D., Liberati, A., Tetzlaff, J., Altman, D. G., Altman, D., Antes, G., ... Tugwell, P. (2009). Preferred reporting items for systematic reviews and meta-analyses: The PRISMA statement (Chinese edition). Journal of Chinese Integrative Medicine, 7(9), 889-896. https://doi.org/10.3736/jcim20090918

Moridi, M. A., Kawamura, Y., Sharifzadeh, M., Chanda, E. K., Wagner, M., Jang, H., \& Okawa, H. (2015). Development of underground mine monitoring and communication system integrated ZigBee and GIS. International Journal of Mining Science and Technology, 25(5), 811-818. https://doi.org/10.1016/j.ijmst.2015.07.017

Şalap, S., Karslioğlu, M. O., \& Demirel, N. (2009). Development of a GIS-based monitoring and management system for underground coal mining safety. International Journal of Coal Geology, 80(2), $105-112$. https://doi.org/10.1016/j.coal.2009.08.008 